\title{
A ETNOGRAFIA COMO EXTENSÃO DA GUERRA POR OUTROS MEIOS: NOTAS SOBRE A PESQUISA COM MILITARES
}

Piero C. Leirner

\section{Introdução}

Pretendo trabalhar neste artigo com um tema pouco explícito na antropologia e que pode assumir diferentes facetas: as relações entre militares e antropólogos. Menos do que retomar toda uma complexa história de relações entre antropólogos e agências estatais - cuja ampla discussão tem sido alvo de um intenso esforço reflexivo na antropologia (Neiburg \& Goldman 1998; Almeida 2004) — minha intenção aqui é analisar algumas consequências do "contato direto" entre antropólogos e militares, seja ele causado por engajamento de antropólogos em instituições militares, seja ele resultado de um "choque cultural" (nos termos de R. Wagner 1981:6-13) ${ }^{1}$ provocado por uma intenção de etnografar militares. Quero começar retratando duas possibilidades para a relação: uma antropologia militar (de "posse" dos militares), e uma antropologia dos militares (relativa aos militares). ${ }^{2}$

Acredito que novos objetos sempre trazem novos problemas. Que se tenha notícia é possível contar nos dedos quantos estudos antropológicos dedicaram-se a realizar etnografias sobre militares. Mais precisamente, e ainda que seja complicado ter uma noção total de número e qualidade de "etnografias de" qualquer coisa, é possível supor com uma relativa margem de segurança que até 2007 eram seis: ${ }^{3}$ uma de um israelense (Ben-Ari 1998); duas de norteamericanas (Simons 1997; Lutz 2002); uma de um argentino (Badaró 2006); e duas de dois brasileiros (Castro 1990; Leirner 1997). Pelo menos os três últimos se conhecem, e compartilharam experiências de campo muito semelhantes. Uma delas, que pretendo desenvolver no âmbito deste artigo, diz respeito ao controle e ao padrão de relação que os militares pretendiam estabelecer em relação aos antropólogos que os estudavam e, se possível, também em relação à antropologia como uma forma de saber útil de seu ponto de vista.

Talvez seja o caso de já esclarecer que não somente a antropologia tem uma utilidade para os militares, como também não é só para militares que ela 
pode ser útil. Toda uma série de agentes - ONGs, missionários, entidades de apoio aos índios, agências financiadoras e outros setores estatais — volta e meia assumem dispositivos de ação tipicamente militares (exemplos vários podem ser encontrados em Lima 1995: cap.1) e fazem uso da antropologia para "fins práticos" e, por sua vez, também são monitorados por militares. Registre-se aqui como parênteses toda uma política católica, por exemplo, a salesiana, de produzir conhecimento a partir de dados colhidos através de monitoramento de trabalhos antropológicos (Montero 2007) ${ }^{4}$; ou então uma série de procedimentos estatais que ao longo do tempo têm procurado regular e controlar o conhecimento antropológico, fato reconhecido e bem explorado por uma extensa bibliografia que lida com a relação entre a antropologia e os interesses coloniais (Asad 1973; Vincent 1990). Assim, embora a inteligência militar possa decantar para um amplo leque de relações - sobretudo aquelas que dizem respeito à administração de "alteridades" (Lima 1995) — cabe destacar que o caso com o qual aqui trabalharei diz respeito a modalidades específicas de "contato direto" entre militares e antropólogos.

Pretendo assim mostrar como as relações entre militares e antropólogos seguem uma determinada direção. No entanto, essa direção pode ser estabelecida de forma compulsória, quando antropólogos passam a trabalhar para militares, ou indireta, quando antropólogos desejam observar militares e acabam por sofrer "efeitos colaterais" de suas etnografias. Como diferença relativa entre estas duas modalidades de relação, imagino que a segunda realize em alguma hora de seu caminho um retorno, e restabeleça o controle relativo à relação. Por esta razão, embora as etnografias "controladas por" militares representem um tema da maior importância, e que de certo modo já foi trabalhado em uma série de estudos que discutem a relação da antropologia com o Estado, aqui elas vão apenas servir como um contraponto inicial para o problema do controle suscitado em campo. Portanto, com base em uma experiência etnográfica com militares, vamos tratar do contexto criado por essa relação, suas armadilhas e pontos de fuga.

\section{Possibilidades de relações entre antropologia e militares}

Embora as relações entre antropólogos e instituições militares sejam antigas, desde 2006 notícias publicadas nos EUA têm retratado uma nova modalidade de se fazer um trabalho antropológico: aplicando-se diretamente técnicas e saberes da disciplina em zonas de combate. ${ }^{5}$ A ideia que impulsiona este projeto tem com propósito último aumentar a eficiência das unidades combatentes em locais onde há focos de insurgência; seu primeiro teste foi 
no Afeganistão, e o sucesso desta empreitada motivou o Departamento de Estado norte-americano a propagar a fórmula, propondo que se tenha nos próximos anos pelo menos um antropólogo em cada batalhão combatente. Mas de onde vem isso?

Sabe-se que por muito tempo o Departamento de Estado norte-americano usou etnografias ${ }^{6}$ - Ruth Benedict seria o caso célebre - e que antropólogos foram oficiais de regimentos nativos - Leach, Evans-Pritchard, Linton, para citar alguns. Estima-se que na $2^{\text {a }}$ Guerra pelo menos uma centena de antropólogos trabalhou em órgãos do Estado ligados diretamente ao esforço de guerra norte-americano (Coon 1947; Price 1998). Um caso clássico, o casal Bateson e Mead, retrata de maneira emblemática este tipo de relação.

No começo do conflito, Bateson (apesar de ser inglês) foi trabalhar no Office of Strategic Services (OSS) norte-americano e, posteriormente, na Marinha, onde desenvolveu, já em solo asiático, programas de contrapropaganda e guerra psicológica aos japoneses. Talvez em um dos momentos mais críticos chegou a se engajar em missões de combate e reconhecimento em solo inimigo:

Gregory Bateson fez muito mais do que simplesmente desenhar um elaborado esquema de propaganda antijaponesa. Ele também ajudou a analisar dados brutos de inteligência, escreveu artigos analisando estratégias de inteligência de longo prazo e, inclusive, se engajou em manobras secretas. Seus arquivos da OSS mostram que, em agosto de 1945, ele foi voluntário em uma "perigosa" missão secreta de dez dias - pela qual foi condecorado - que exigiu que se esgueirasse entre linhas inimigas para tentar salvar agentes aliados capturados (Price 1998:380).

Aparentemente, algumas teorias de cunho conspiratório sugerem que o esforço de Bateson e sua ligação com o então diretor da OSS, Bill Donavan, resultaram em uma suposta ligação com a criação da CIA, e que ele ainda tenha participado ativamente de uma operação denominada "MK-Ultra", especificamente elaborada para desenvolver mecanismos de controle mental e cenários de guerra psicológica. Mesmo que Bateson tenha tido certo desgosto com a prática da contrapropaganda e os usos da guerra psicológica durante a $2^{\text {a }}$ Guerra, tal qual Margaret Mead, é notável que ambos tenham se colocado a serviço da máquina de guerra até depois do conflito. Junto com Bateson e Geoffrey Gorer, Mead ajudou o OSS a estabelecer uma unidade psicológica de treinamento de guerra para o Extremo Oriente (Mabee 1987:8). Ainda assim, é patente que não se pode reduzir Mead, Bateson e tantos outros antropólogos a estes aparelhos de Estado. 
Apesar de as relações entre militares e antropólogos não chegarem a causar maiores espantos, dadas as dimensões do projeto colonial que de certo modo assombraram a antropologia num período da sua história (Asad 1973; Stocking 1991), ${ }^{7}$ é sabido que em parte foi uma mobilização antitotalitária e antinazista que levou antropólogos como estes ou como Ruth Benedict a este tipo de engajamento (Neiburg \& Goldman 1998:57-ss.). ${ }^{8}$ Seja como for, os manuais de estudos de "cultura à distância", os panfletos para a "moral" de guerra e os estudos de caráter nacional - constituindo o tripé "conhecer os inimigos, os aliados e a si mesmo" (cf. Neiburg \& Goldman 1998:64-65) — aparentemente se constituíram em um protoplasma para que as agências estatais procurassem ressuscitar essas práticas em uma versão nova.

Militares estão atentos ao mundo acadêmico e, cedo ou tarde, alguém se lembraria desses fatos e chegaria novamente ao engajamento da antropologia no terreno da guerra. No entanto, o que parece um pouco diferente neste caso é o fato de que os militares expandiram seu terreno de controle, assumindo eles próprios os serviços antropológicos, fosse formando antropólogos (isto é, enviando agentes para a academia), fosse convertendo antropólogos em militares (isto é, anexando o antropólogo formado à farda a partir de mecanismos de conversão do antropólogo civil em militar). Em ambos os casos trata-se de ir para um novo campo de relações, bem além da cooptação de civis para trabalharem com militares. Agora se trata de trabalhar como militares. Como isto se deu?

O que se tornou público e notório nessa história é que um militar, extenente-coronel das forças especiais do exército australiano, David Kilcullen, fez seu doutorado na Universidade de South Wales (Austrália) sobre um movimento insurgente na Indonésia - movimento Darum Islam, que durou cerca de uma década, entre os anos 1950 e 1960 - e publicou uma série de artigos em periódicos militares sobre movimentos de insurgência, guerrilha, terrorismo e o Islam. A tese, defendida na área de política e intitulada "Political consequences of military operations in Indonesia 19452000: A fieldwork analysis of the political power-diffusion effects of guerrilla conflict", baseia-se numa metodologia "usada na antropologia, baseada em pesquisa de campo e observação participante" (Kilcullen 2000: Apêndice 1). ${ }^{9}$ Posteriormente, Kilcullen insistiu, em artigos publicados em periódicos militares, na necessidade de se empregarem técnicas da antropologia em campo, como uma possibilidade de se mudar do paradigma da "força" para o da "inteligência". ${ }^{10}$ Não demorou muito para que seus artigos entrassem para a agenda das Forças Armadas norte-americanas e, a partir daí, iniciar uma carreira como assessor especial de Condoleezza Rice para assuntos relacionados à contrainsurgência no Afeganistão e no Iraque. ${ }^{11}$ 
Kilcullen e um antropólogo norte-americano, Montgomery McFate, elaboraram um plano explícito de prospecção e análise cultural para conduta em teatros de operação que envolvessem movimentos de contrainsurgência. McFate, que em 2005 já havia lançado mão de uma ligação histórica entre antropologia e o Departamento de Defesa evocando a série de estudos de caráter nacional no periódico Military Review (McFate 2005), apelou para as possibilidades táticas do uso da antropologia por tropas. ${ }^{12} \mathrm{E}$ o produto mais bem acabado disto está em um manual de operações de contrainsurgência lançado em fins de 2006:

Em 15 de dezembro de 2006, o Exército dos Estados Unidos divulgou um novo manual de contrainsurgência, o FM 3-24, uma publicação conjunta do Exército e do corpo de fuzileiros navais (N.A.). É o primeiro manual dedicado exclusivamente à contrainsurgência em mais de 20 anos. Pelo menos um antropólogo desempenhou um papel na elaboração deste documento de 282 páginas: Montgomery McFate, um antropólogo norte-americano, co-autor de um capítulo intitulado "Inteligência na Contrainsurgência", escrito em conjunto com um especialista em inteligência militar. Além disso, o Pentágono adaptou o trabalho de David Kilcullen, um oficial de infantaria australiano, em um apêndice intitulado "Um guia para a ação". Embora os meios de comunicação tenham relatado amplamente que Kilcullen é um antropólogo, na verdade, ele é doutor pela Faculdade de Política da Universidade de Nova Gales do Sul (Gonzáles 2007:14).

Não quero supor que a antropologia e os militares começaram um novo contexto de relações baseado em um único personagem que, por acaso ou por convicção, realizou a "pivotagem" necessária para que concretamente as engrenagens se encaixassem. Porém, como nas instituições militares os postos mais altos tendem a propagar um habitus na rede, é possível que as conexões formadas nos altos escalões, que acabaram por incluir Kilcullen, tendessem a se instituir como fatos culturais exemplares: "solidariedade hierárquica", Sahlins diria (1990:70-71). No caso, peças importantes do contexto militar foram acionadas:

O interesse militar pela cultura coincide com uma grande mudança dentro do Pentágono - a ascensão ao poder de "um pequeno grupo de guerreiros- intelectuais" na era pós-Rumsfeld, liderada pelo General do Exército norte-americano David Petraeus, o novo comandante no Iraque [Comandante no Iraque desde o começo de 2007, Petraeus foi promovido em abril de 2008, assumindo o comando de toda uma área que inclui Iraque, Afeganistão e Somália]. Petraeus, 
que tem doutorado em relações internacionais por Princeton, formou recentemente uma equipe de doutores em ciências sociais, que teve sua importância aumentada quando a administração Bush passou a tentar desesperadamente melhorar a situação no Iraque. Esta iniciativa tem recebido ampla cobertura midiática, incluindo um simpático perfil do círculo íntimo de Petraeus na capa do Washington Post, notadamente Kilcullen, que se encontra nos EUA "a título de empréstimo" do governo australiano para os militares norte-americanos (Gonzáles 2007:17).

Embora não seja exatamente uma novidade o fato de que militares norte-americanos circulem nas coteries da "elite do poder" - como já atestava C. Wright Mills em 1956 (1981 [1956]) — e que estas eventualmente incluam também acadêmicos, há algo inusitado no ar. Em alguma medida esse movimento já está irradiando para "as bases" militares, pois a essa altura mais gente decidiu abraçar a causa, e não faltam antropólogos americanos se formando com este fim. Neste ponto, imagino que esta seja uma via de mão dupla, pois também afeta a antropologia, já que incide diretamente sobre o campo de atuação profissional dos seus quadros. Ainda que a reportagem da Newsweek supracitada (nota 4) fale em um soldo de 300.000 dólares anuais para esses antropólogos, não há evidências de que esta seja a única causa de atração; alguns chegam a mencionar um "espírito de aventura"; outros mencionam a guerra como uma possibilidade de antecipar, epistemológica e financeiramente, uma pesquisa de campo no Iraque ou no Afeganistão.

Pode ser que este seja um problema restrito à antropologia norte-americana (falando hoje, pois a perspectiva do Império esteve presente também em outras antropologias [Neiburg \& Goldman 1998; Stocking 1982]) que, no mais, já teve setores com uma visão francamente utilitarista da antropologia (contra os quais se rebelaria Sahlins, com sua visão francamente antropológica contra o utilitarismo [1981]). Ao menos em relação à subárea chamada de "antropologia da guerra", há indícios que mostram que de algumas maneiras o campo norte-americano tem imbricado antropólogos e militares há já algum tempo. Um dos primeiros antropólogos a falar em "antropologia da guerra", H. Turney-High, era militar, e sua tese The Practice of Primitive War (1942) ${ }^{13}$ — é uma espécie de laboratório para as teorias de Clausewitz que, de maneira torcida, enfrentavam a prova de campo com as pretensões alemãs de "guerra total".

Visões mais recentes - em muito herdeiras de Turney-High (Otterbein 2000) - que ecoam dados da ecologia cultural e da sociobiologia (Chagnon 1988 é o exemplo paradigmático), ou do materialismo (Ferguson 1984), ${ }^{14}$ 
frequentemente são citadas em estudos de estratégia e história da guerra realizados por militares ou colaboradores próximos (cf. K. Otterbein 2000). Finalmente, os exemplos de etnografias de militares que estão, vamos dizer, em um círculo norte-americano, têm uma ligação direta com militares: BenAri é um militar israelense e sua tese sobre a Palestina é uma "participação observante"; Anna Simons é esposa de um Boina-Verde (tropa de elite do exército americano) e em vários pontos ela faz etnografia de si mesma; Margareth Harrel e Pamela Frese são esposas e filhas de militares e trabalham em cooperação com órgãos de defesa dos EUA.

Claro que nem tudo precisa estar envolvido por essa cortina de fumaça. Ainda que os antropólogos possam se interessar pelas guerras, isto não significa que eles precisem se situar como "intelectuais orgânicos"15 das instituições que as promovem (e, do mesmo modo, antropólogos podem se interessar por religião sem serem clérigos, por canibalismo sem serem canibais etc.) ${ }^{16}$ Se de fato há uma ligação orgânica entre esses campos (antropologia da guerra/guerra), este é um ponto difícil de demonstrar, que mereceria um estudo empírico que verificasse como a antropologia da guerra é usada em contextos militares. De todo jeito - imagino - como a observação afeta o objeto, e como o objeto afeta o observador, é preciso modular as doses, as expectativas e os efeitos colaterais de "participação observante" que a "antropologia da guerra" suscita.

Mas isto posto, é interessante ter em mente que a ação do exército em cooptar acadêmicos para converter a "cultura inventada" pelos antropólogos (nos termos de R. Wagner 1981) em prospecção bélica nem sempre é vista a olho nu, e frequentemente se estabelece de modos sutis. Se este é o caso de grande parte de uma antropologia do Império ou do Estado-nação, muito tempo se passou até que se chegasse a falar disto na disciplina. Pelo menos em fatos recentes temos uma vantagem: o caso Kilcullen \& cia. foi suficientemente escandaloso para que protestos surgissem intensamente na AAA. E certamente não podemos falar que tal movimento de cooptação é respaldado pela má fé da antropologia.

De certa maneira, esta extensão do aparelho de Estado está em termos práticos muito além da capacidade de organização dos antropólogos. Diria até que ela se realiza através de dispositivos de "torção" das relações — tal qual buracos negros torcem os comprimentos de onda que passam perto deles, podemos observar seus efeitos. Para tanto, são estabelecidas agências de intermediação, fundações de fachada e fontes de financiamento aparentemente desconectadas das Forças Armadas. O exemplo - provavelmente o mais contundente dessa política - seja a RAND Corporation, organização criada nos EUA, ao fim da 2a Guerra, com o objetivo de manter o aparelho 
industrial-científico-militar operando a todo vapor. Seu staff inclui, ou incluiu, vários prêmios Nobel e cientistas das mais variadas áreas de atuação trabalhando na chave da "segurança norte-americana". Em seus quadros está uma co-autora (Margareth Harrel) do volume Anthropology and the United States Military (Frese \& Harrel 2003).

Este certamente é um dos lados do problema: em princípio, não temos quase nenhum controle sobre as fontes que permitem a realização, e talvez muito menos ainda sobre os destinos de nossas etnografias. Mas, de outro lado, seria possível afirmar com total certeza que algum dos lados tem controle absoluto sobre o outro? Creio que não - nem militares podem estabelecer as convenções de antropólogos, nem antropólogos as de militares. O que podemos fazer, então, para entendê-los sem nos tornarmos "agentes a serviço de..."?

Um dos recursos que temos é retornar o sentido da observação: se, para começar, os antropólogos estão sendo observados por militares, nada mais justo que o caminho de volta também seja realizado, e passemos a observar o que eles estão observando. Este foi o meu caso pós-pesquisa de campo, e devo adiantar que cheguei a esse pé por conta do fato de que estava realmente sendo observado por militares que, volta e meia, me sondavam para saber o que estava pensando deles. Um outro movimento que ilustra esta situação apareceu justamente numa tradução inventiva que militares fizeram de minha tese, adaptando as ideias de "informante", "observação", "objeto" e outros termos à situação de "campo" deles: o combate. ${ }^{17}$ Neste caso, até para redobrar o movimento de observação, passo a questionar se a etnografia de militares tem como escapar da imanência da lógica da guerra que estabelece as convenções no mundo dos militares. Em outros termos, tomo como ponto de partida o dado etnográfico que me diz que o controle que os militares querem ter sobre o mundo é uma extensão lógica da guerra que eles inventam (remeto novamente esta ideia à noção de "invenção" nos termos de R. Wagner [1981], como sentido criativo de relação com o mundo).

Vale sublinhar: a ideia que eles tinham de "guerra" era diferente da minha até então.

O que percebi, neste sentido, é que o mundo "dado" — convencional — depende de novos contextos e metáforas que militares, por sua vez, objetificam, inventam. Assim o fazem de maneira análoga ao antropólogo, que "usa a noção de cultura para controlar suas experiências de campo, [e] essas experiências, por sua vez, passam a controlar a sua noção de cultura" (Wagner 1981:11). Tome-se então que para militares "a guerra opera como cultura" - o que a nosso modo pode ser recolocado como "a cultura que opera como guerra". O que é convencional e inventivo, para antropólogos 
e seus "objetos", atua assim em "reciprocidade dialética". Desta forma, convenção e invenção podem ser entendidas, nos termos de Wagner, como duas potências que atuam no mundo e o constroem, seja como elementos identificadores, seja como diferenciadores: "A necessidade da invenção é dada pela convenção cultural, e a necessidade da convenção cultural é dada pela invenção. Inventamos para sustentar e restaurar nossa orientação convencional; aderimos a esta orientação para efetivar o poder e os ganhos que a invenção traz" (1981:52). Neste caso, parafraseando Sahlins (1990:12), se militares fazem as guerras, as guerras fazem militares. À maneira de Wagner, penso que também a etnografia passa por este duplo processo: invenção e convenção.

Nesta linha, o caso que pretendo relatar daqui para frente é resultante de uma encruzilhada vivida em campo. Trata-se de rever o que sobrou do "choque cultural" que resultaria da experiência etnográfica. Um ponto eu já adianto: sempre houve, desde o início da pesquisa, uma tentativa de cooptação dos militares para que "trabalhasse com/para/como" eles. Outro aspecto que posso adiantar é que o outro lado não gostava muito de ser tratado como "pesquisado". Embora não chegassem a hostilizar a posição, era estranho para eles que "alguém que cuida de índio queira nos entender".

Estamos falando de 1992 e de uma história que se estendeu até os dias de hoje. Pretendo agora mostrar como certos "efeitos colaterais" da etnografia revelaram uma percepção sobre o modo com que o exército opera sua vida social, bem como sobre as modalidades de projeção desta vida sobre um "campo ou sistema da guerra". A questão pode parecer estranha a qualquer um que tente falar em guerra a partir de uma etnografia com militares brasileiros, considerando que o Brasil não participou ativamente de nenhuma guerra desde 1945 - embora tenha tido algum papel em uma ou outra missão de paz das Nações Unidas - e que militares latino-americanos sejam mais recordados pela sua participação na política como atores de golpes do que qualquer outra coisa. O estranho, porém, é que esses nativos não vêem a coisa assim: "Quem disse que não estamos em guerra?" - era o que eu ouvia nos meus primeiros contatos com eles. Este ponto, crucial na lógica do entendimento nativo, introduziu um "choque cultural" que produziu o resultado etnográfico que se segue.

\section{Efeitos da Cadeia de Comando}

O primeiro contato que tive com militares foi no ano de 1992; antes disso eles eram para mim uma realidade estranha, exceto pelo que já havia lido 
sobre o tema. Foi por insistência de minha orientadora - Maria Lúcia Montes - que dizia que alguém deveria "estudar esta tribo desconhecida", que me interessei pelo tema. Através de um contato arranjado por ela própria, cheguei nessa época à Escola de Comando e Estado-Maior do Exército (ECEME), situada no Rio de Janeiro, levando comigo um caderno e um "projeto", elaborado como uma carta de intenções, em que pontualmente sumarizava um programa de pesquisa que visava sobretudo à ida para a região amazônica, provavelmente perto de São Gabriel da Cachoeira (estado do Amazonas) e à estadia, por um período de pelo menos 6 meses, em um pelotão de fronteira nessa região. A primeira recepção foi pautada por reciprocidade; dei o projeto, telefones, endereços, e ganhei de volta uma apostila com vários textos ${ }^{18}$ para "estudar e posteriormente apresentar um resumo": "Isto é o que fazemos aqui" — disse-me um oficial.

Por mais de dois anos esta se tornou uma rotina. Em períodos intermitentes, passei meus dias frequentando atividades nesse mesmo local e vendo as possibilidades de uma autorização para sair de lá e etnografar pelotões se fecharem cada vez mais. Em vários momentos entendi que havia uma mensagem subliminar: "lugar de universitário" era naquele espaço, o qual era, por sinal, o que havia de mais parecido no mundo militar com a academia universitária civil. Mais do que isso, era lá que em alguma medida eu poderia chegar perto "do que pensa um militar" e, embora não tivesse percebido isto então, minha presença causou algum efeito segundo a perspectiva deles, pois em um dado momento houve uma insistência para que saísse da universidade e ingressasse no exército. Tinha então por volta de 25 anos, e isto ainda era possível de acontecer. Às vezes eu sentia certa frustração por parte de alguns oficiais pela minha recusa, sempre generosamente explicitada com algo do tipo "seu papel aqui é mais importante" — frase aliás que replicava vários discursos antes ouvidos, em que se dizia que eu podia ser uma "peça fundamental no estreitamento de laços entre instituições que tinham a missão de construir um projeto para o Brasil".

Boa parte do que foi construído na relação assim estabelecida foi elaborada a partir dessa sistemática tentativa que eles faziam de estabelecer uma política de "estreitamento de laços" com aquilo que entendiam como "a universidade". Note-se que ela era tomada pelo singular, fato à época interpretado como uma leitura às avessas de sua própria corporação, isto é, uma espécie de réplica "à paisana" que supostamente guardaria duas das principais propriedades para a percepção de uma simetria: hierarquia e disciplina (Leirner 1997). Entendi que estava naquele momento entrando em uma zona cinzenta, que depois das etapas canônicas da relação do pesquisador com seus nativos - que inclui um "choque cultural", troca de 
gentilezas, tentativa de entendimento recíproco, estabilidade simbólica no arranjo que servia de tramitação nas associações que eu e eles realizávamos e, finalmente, controle sobre todo esse processo de aprendizado, objetificando-o em "cultura": invenção controlada de um "objeto" (R. Wagner 1981:44-ss.) - me foi permitido retomar as relações que vivi em termos de uma etnografia.

À época não me passou pela cabeça que militares, como etnógrafos, "inventam" uma cultura (idem) e que todos esses eventos poderiam ser tratados como "fatos etnográficos". Dei pouca atenção a isto, pois para realizar a pesquisa eu pressupunha a continuidade dessa política e a via como uma espécie de evento preliminar à própria pesquisa de campo. O que eles chamavam de "aliança", "laços" e "política" certamente não eram as mesmas coisas que significavam para mim; na melhor das hipóteses, eram conceitos embebidos em uma série de noções do senso comum ou da ciência política, da sociologia ou mesmo de uma antropologia distante desse "objeto".

Mas se tais conceitos em suas mentes sofrem uma espécie de "torção criativa", ou "invenção", caberia a mim revê-los e tentar retraçá-los a partir de uma outra perspectiva. Assim, hoje, afastado da necessidade imperiosa de estar em campo, posso redimensionar o significado dessas ideias de "política", "aliança" etc. entre militares e "universidade". De um lado, imagino que tais noções devam ser englobadas por uma gramática da guerra, razão de ser deste objeto; de outro, posso aproximá-las de um idioma da guerra que me é familiar pela literatura antropológica: assim, vejo essas relações se assemelharem à permanente tensão que governa a aliança entre cunhados que, no caso, estavam estremecidas e precisavam ser retomadas a partir de uma troca "pacificadora". ${ }^{19}$ Estranhamente, cheguei a ouvir certa vez de um general da reserva, ex-ministro, algo como "E aí? Como vocês estão lá na universidade? Continuam aquele bando de comunistas?". Soava como alguém que não via o outro há muito tempo, pronunciando palavras cordialmente desconfiadas - "inimigos fiéis", tomando de empréstimo a ideia de Carlos Fausto (2001).

Se essas noções estão de fato indexadas à guerra, fica claro o porquê de eles enxergarem a universidade como uma espécie de espelho hierárquico e disciplinado. A universidade seria como um exército; o conhecimento, a disciplina; a ciência, a estratégia; a antropologia, a espionagem; o etnógrafo, na ponta da lança, o agente duplo, que é ao mesmo tempo informante e propagador das ideias. Assim, também a política pode ser concebida através da "continuação da guerra por outros meios", como colocou Foucault (1999), invertendo o célebre aforismo de Clausewitz. ${ }^{20}$ Trata-se de levar a sério a ideia de que "estamos em guerra": ela não é o fenômeno que eu percebia 
através de batalhas, ou aquilo que antes via como "esta ou aquela" guerra que se ganha ou se perde. Na perspectiva nativa, ela é um estado, uma potência que se coloca a todo o momento, e que eventualmente está sendo dissuadida. "Se você não percebe a guerra, é porque estamos dissuadindo o inimigo" - insistiam os militares.

Não se trata de simplesmente reproduzir o argumento nativo. Procurando uma noção que desse conta desse argumento, percebi que a guerra não poderia ser compreendida como fato concreto, mas antes como relação, e este é um ponto com o qual estamos mais acostumados na antropologia. Estou entendendo a guerra como uma modalidade de relação social, a relação entre inimigos recíprocos. Enfim, não há como a noção nativa deixar de afetar minha própria noção e, assim, procurarei a partir desta indexar também outras. A "aliança", por exemplo, ou a "troca". Na bibliografia, tais noções já foram tomadas como uma modalidade de guerra, ou ao menos relacionadas a ela (Lévi-Strauss 1976 [1943]; Clastres 1980; Fausto 2001). Em campo, a "aliança" foi tarefa de uma agenda de "estreitamento de laços"; a "troca" entre instituições e entre o etnógrafo e seus pesquisados englobada pela hierarquia e pela disciplina - efeitos da cadeia de comando. Tais relações, digeridas por um cotidiano militar que está imbricado à guerra, de algum modo também foram transferidas para o etnógrafo. A etnografia, neste caso, passou a ser uma extensão lógica da guerra - uma relação à maneira dos militares.

Pois bem, não estou só falando de coisas que aconteceram logo nos primeiros contatos: vigiar (e punir), pois hoje se repetem com alunos que oriento e que resolveram entrar no tema. Chegando a uma unidade militar, de antemão o etnógrafo está esquadrinhado; sabe-se "quem ele é", como e por que ele está lá; alguém o espera; alguém o conduz para aquele que foi designado para recebê-lo; aquele que o recebe já diz: interessa-lhe isto ou aquilo, e você vai fazer tal coisa. "É isto que deve ver". Hoje percebo que tal atitude é decorrente de algo que esses nativos sempre me falavam: "militar pensa prospectivamente", tem que antecipar o inesperado. É verdade que antecipar o inesperado em seus quadros culturais não é um privilégio de militares; havaianos o fizeram e muitos outros o fazem (Sahlins 1990, 2007), mas poucos fazem disso um exercício consciente que transforma categorias culturais em pronta ação.

O etnógrafo, como o estrangeiro, tem que ser prospectado. Como isto começa? Como primeiro passo, em um contato, é preciso antes de tudo uma carta oficial da instituição do etnógrafo, passando por instâncias como orientador, chefe, unidade, universidade. Mas talvez não seja suficiente. Pedidos são feitos para que os chefes imediatos do etnógrafo - orientador, 
chefe de Departamento ou unidade - de alguma forma indiquem que estão eles próprios envolvidos no processo. É o primeiro sintoma de que a hierarquia se compromete com o etnógrafo, que a cadeia de comando pode ser afetada se algo der errado. E aí um fato que nos interessa: se o etnógrafo muda a unidade militar que quer estudar, o passo deve ser repetido: de novo, manda-se uma carta de intenções de pesquisa chancelada pela instituição. Mas não é só: se o etnógrafo é substituído por outro, mesmo que se repita a unidade militar, novamente se deve recorrer a esse passo. E ainda: caso o mesmo etnógrafo queira novamente pesquisar uma unidade já visitada após um período, o primeiro passo deve ser repetido.

Este procedimento também é efeito da cadeia de comando. Embora a percepção que o senso comum tem sobre a hierarquia militar aponte para uma "pirâmide de estratos", o que ocorre é uma composição bem mais detalhada e complexa: cada indivíduo aparece em um lugar singular da cadeia, duas pessoas jamais estão na mesma posição, sempre há alguém que comanda e alguém que obedece imediatamente "antes" e "depois" de cada um. Quando a cadeia de comando "se move", por exemplo, na época de promoções, seus indivíduos movem-se juntos, trocando de posto (Leirner 1997). Assim, a contrapartida desta movimentação para o etnógrafo é retomar do zero a relação, pois na medida em que a cadeia se refaz, também o etnógrafo "deixa de existir" em suas propriedades anteriores para a seção particular que se tenta abordar. Cabe notar que eu próprio passei por esta situação algumas vezes, assim como a repasso através de meus orientandos (e eles a mim, em um ciclo interminável e, diga-se de passagem, enervante).

Tal situação aponta para uma relação peculiar entre indivíduo e coletividade pouco estudada em suas formas pela literatura sociológica e antropológica. Tudo se passa como se determinações coletivas simplesmente englobassem o indivíduo, ${ }^{21}$ mas notavelmente esta hierarquia especializou-se tanto que ela se reproduz em termos de um a um, portanto, aparece como uma "hierarquia individualista". Um dos seus efeitos para o etnógrafo é que ele é percebido como um "representante" de sua instituição, ao mesmo tempo em que esta tem que passar a chancela de sua "cadeia de comando".

Uma das coisas mais extraordinárias que ouvi repetidas vezes em campo foi o questionamento se era "amigo ou inimigo do exército", que "fulano era amigo do exército", ou que outro "era amigo, mas depois se tornou inimigo do exército". No começo pensei que era mera força de expressão, mas posteriormente vi que a modulação amigo/inimigo é absolutamente central como categoria nativa. Sua centralidade se deve, sobretudo, à quantidade de dimensões que consegue articular: países, exércitos, comandantes, políticos e simples etnógrafos podem ser amigos ou inimigos do exército. 
De certa maneira, essa indistinção de escala pode ser entendida como um dos principais efeitos da cadeia de comando, por isso abrange do etnógrafo ao exército alienígena. Mas o que ela revela principalmente é que a categoria "amigo/inimigo" está imbricada à cadeia de comando, isto é, que ela pode ser percebida como uma "extensão da guerra por outros meios". É preciso aqui adicionar alguma informação etnográfica para que se entenda o alcance desta proposição.

Observar o cotidiano de militares em atividade pode evocar perguntas como "o que o modo com que se senta à mesa tem a ver com o modo com que se combate?". Este tipo de questão volta ao ponto da prospecção, bem como da codificação do cotidiano da vida militar. Apropriando-se da ótica daqueles que ingressam na carreira militar, quais fatos cotidianos marcam sua socialização? Como mostra a pesquisa de C. Castro (1990), realizada a partir de uma etnografia com os cadetes da Academia Militar das Agulhas Negras (AMAN), o indivíduo ingressante, desde o primeiro momento dos quatro anos de estadia em regime de internato, é submetido a uma bateria de rituais expiatórios, treinamentos físicos e repetição constante de recursos mnemônicos, cuja função parece ser a inculcação "naturalizada" ou a "ação de decorar"22 princípios militares. ${ }^{23}$ Tais mecanismos parecem ter uma dupla finalidade: a) estimular uma constante desistência entre os cadetes, de modo que os perseverantes incorporem a noção de que têm uma "vocação natural" para a vida militar; b) forjar a construção de uma nova pessoa, cuja nova identidade é reconhecida a partir da ideia do pertencimento a um "mundo de dentro".

Tal reconhecimento se dá sobretudo pela constante atualização de princípios de entendimento da realidade em função do ordenamento hierárquico (Leirner 1997) e de características marcadamente holistas (cf. Dumont 1992). Concretamente, isto é considerado pelos nativos tendo em vista o emprego da disciplina. Diferente de "nós" (que para eles somos paisanos, mas principalmente "nós" da universidade, principal contraponto comparativo de oficiais), que temos diversas disciplinas e transitamos por elas como uma parte de nossas vidas, os militares têm todo esse regime prescritivo condensado em uma única fonte de "capital militar", reconhecida como a disciplina. Assim, se nossa etiqueta pode estar dissociada de nossas "disciplinas" intelectuais (posso ser um antropólogo brilhante e de maneiras grosseiras, ou medíocre, mas polido), não podemos dissociar a etiqueta da disciplina militar — os próprios regulamentos militares prevêem rigor tanto para uma formação de combate, quanto para um desfile, ou mesmo para entrar em um elevador.

Na caserna, não só sentar à mesa, mas também andar em um corredor, dirigir a palavra, cumprimentar um colega, realizar um funeral, escrever um 
memorando, entrar em um automóvel etc. e combater passam pelo mesmo regime prescritivo. Devem ser seguidas ordens e disposições que são fixadas pela cadeia de comando, as quais geralmente se encontram disponíveis a qualquer militar em regulamentos disciplinares e de etiqueta. Por exemplo, no Exército brasileiro, sentar-se à mesa obedece à seguinte disposição: no centro senta-se primeiro o superior (vamos tomá-lo como "ego") e, em seguida, pela ordem hierárquica, sentam-se os outros, dispondo-se imediatamente à direita de ego, depois à esquerda, repetindo-se até completarem os lugares. Em um manual básico de operações de assalto de infantaria, em princípio, segue-se a mesma disposição supondo linhas de combate, sempre tendo em vista que um dos objetivos máximos é preservar a cadeia de comando.

Como contraexemplo, supor a quebra desta cadeia gera uma espécie de horror incestuoso entre militares. Em um caso que vi em campo, me foi contada uma história acerca da relação entre um oficial e um subordinado que se situava várias escalas abaixo de seu "círculo hierárquico". A classificação nativa que se dá para este tipo de relação é a noção de "promiscuidade", para eles associada a uma série de tabus e tomada como um dos piores horrores que podem acontecer na vida de um militar. Forte o termo, evocou a série de restrições e regras que marcam o jogo da aliança e, assim, mais uma vez, me fez pensar que a cadeia de comando é mais um caso de aliança enquanto relação social. A guerra imprime seu sentido para a cadeia de comando. Tratase, enfim, de um ordenamento do mundo, e a ideia de "promiscuidade" pode muito bem ter vindo à tona para evocar um princípio geral de classificação, algo como "cada um em seu lugar", o que obviamente inclui o etnógrafo e suas pretensões. Como explicitei em outro texto (Leirner 1997), um recado foi dado de forma muito clara em outra ocasião: "Piero, sopa quente se come pela borda". É preciso sempre estar atento para qual lugar se ocupa nessa cadeia, e a partir daí saber quais trocas são possíveis e quais não são.

Curioso notar que estamos falando de uma realidade, como observou Castro (1990), em que claramente há uma separação entre nós e o "mundo de fora", e que estes dois mundos também ocupam lugares diferentes nessa hierarquia fundada pela guerra. Se no nosso mundo - por suposição, "científico", ou pelo menos aquele dos valores ou da cultura "inventada" pelos antropólogos - decorar ideias torna-se uma forma menor de concebêlo, mais valendo leituras duplas, paradoxos e convivência de paradigmas antagônicos, no mundo militar a constante marcação repetitiva da realidade sugere que os termos e os conceitos necessitam de uma tendência unificadora da palavra e da ação.

Esta forma de ler (e produzir) a realidade, evidentemente para o nosso ponto de vista, também está sujeita a ambiguidades (por certo, como qual- 
quer outra); no entanto, para os militares, trata-se de (procurar ao máximo) convergir sempre para uma visão unificada. ${ }^{24}$ Assim, "sentido!" significa a correspondente postura corporal imediata: procura-se suprimir ao máximo (de maneira ideal, totalmente) o intervalo entre a ordem e a sua consumação em ato, entre comando e obediência. ${ }^{25}$ Note-se que o etnógrafo, aos poucos, tem que apontar um vetor que vá no sentido deste registro se quiser continuar pesquisando militares. Aliás, isto vale para outros pesquisadores que, volta e meia, aparecem em meios militares. Por exemplo, soube de situações em que entusiasmados alunos de Relações Internacionais se "militarizavam", andando em marcha, cadenciando a voz de forma peculiar, cantando o Hino Nacional de maneira marcial.

Este é um dos efeitos de dispositivos que procuram "minimizar" no indivíduo - seja ele o ingressante nas Forças Armadas, seja aquele que quer conviver com militares - as suas características paisanas até alcançar uma pretensa "essência militar" naturalizada; de outro lado, pretende-se preencher com algo o que está lá ${ }^{26}$ (assim, todos somos militares em potencial e, "por isto", segundo eles, "enquanto o humano for humano, haverá guerra"). A engenharia social que realiza esse feito baseia-se sobretudo em um dia-a-dia ritualizado, inteiramente marcado pela repetição de um ordenamento da realidade. Tal fato é traçado por uma diagramação constante dos horários e dos modos de conduta; de reconhecimento automático de dispositivos de ação, como ordens, posturas corporais e etiqueta, e também o reconhecimento de símbolos e notações, como os emblemas e os sinais que se estampam nos uniformes, finalmente, de uma terminologia marcada pelo emprego de uma linguagem cifrada por meio de siglas e termos nativos (cf. Leirner 2008).

Assim, imagino, também são vividos e codificados os sinais externos que se produzem em eventos, como uma pesquisa etnográfica sobre eles (para não fugirmos do assunto). Codificar e ritualizar a vida do etnógrafo é, nesse sentido, um dos maiores sinais de que se entrou para a vida nativa e que, de alguma maneira, já se faz parte da "tribo", seja como amigo, seja como inimigo. Para voltar aos "efeitos colaterais" dessa relação, sua "afetação", como sugere J. Fravet-Saada (2005), emite vários sinais que podem ser detectados nas transformações do etnógrafo: no meu caso, paranoia, mania de perseguição, sensação constante de estar sendo vigiado. Por exemplo, não foram poucas as vezes que percebi interferências em ligações telefônicas; fiquei particularmente suscetível às histórias de bases secretas sob o Lago Norte de Brasília, conspirações internacionais e uma constante impressão de que o mundo estava por um fio. Durante dois anos procurei, como parte dos afazeres que me ditavam, decorar princípios da "arte da guerra", fosse 
lendo exaustivamente Clausewitz ou Sun-Tzu, para que pudesse entender que "a vida é guerra e interesses", como me diziam.

Curiosamente, alunos meus também tiveram lá suas "afetações" (FavretSaada 2005): uma aluna, depois de passar duas semanas em um regimento, ficou meses repetindo o padrão horário a que foi submetida, além de "voltar com uma enorme paranoia de organização que antes não existia (sic)". Outro aluno, exaurido com os procedimentos relacionados às tentativas de pesquisa, se deu "por vencido" diante das inúmeras correspondências que voltavam pedindo "mais detalhes", "mais explicações", "reencaminhe para outra seção", e ele percebeu que este era um ciclo sem fim. Metódico, em certos aspectos um "espelho civil" de disciplina militar, o aluno se perdeu nessa temporalidade inesgotável dos engavetamentos de processos por parte de seu objeto. Em outros casos, vi pesquisadores ficarem impotentes diante da velha sensação de abandono etnográfico ao se voltar à "estaca zero" depois que a cadeia de comando circulou e ninguém deixou isto avisado. Finalmente, em um momento ocorrido já há alguns anos, discutindo diferenças com pesquisadores da área ("milicólogos", como se diz), mas que não realizaram etnografias com militares, Celso Castro e eu chegamos à conclusão de que há realmente algo implicitamente diferente na qualidade das informações coletadas a partir da hora em que se está na posição de um "paisano" - termo e categoria pejorativos com que os militares definem os civis (cf. Castro 1990), algo bem diferente de ser um "pesquisador".

Não quero supor que essas reações sejam pura psicologia de alcova e, embora elas ocorram dentro de contextos psíquicos, só puderam acontecer por terem sido provocadas pelo contexto etnográfico. Assim, interessa ver como e por que essas transferências, projeções ou afetações foram geradas, e transformar o dado psíquico em dado antropológico. Desta forma, gostaria de finalizar este artigo voltando à ideia de que o tipo de troca etnográfica que ocorre na pesquisa de campo com militares pode ser entendido como "uma extensão da guerra por outros meios".

\section{Tipo de Transação}

Uma pesquisadora de militares revelou-me o seguinte caso, ao entrevistar um oficial reformado (aposentado) de um exército europeu:

Veja... tudo bem que você chegou aqui por indicação do coronel " $\mathrm{X}$ ", que é meu conhecido. Estou reformado, estou fora, por isso posso falar as coisas. Mas se estivesse na ativa, nem me preocuparia com o fato de você sequer ter me 
apresentado um cartão de visitas. Antes de você chegar, já saberia quem é, de onde vem e o que quer. Saberia provavelmente o que queria perguntar, e já teria as respostas. Na ativa não perdemos tempo com apresentações (comunicação pessoal da pesquisadora a mim, realizada em 07/02/2008).

Normalmente, quando vemos em monografias (às vezes sumárias) as indicações da relação estabelecida entre o etnógrafo e os membros do grupo estudado, é comum que o antropólogo assuma uma posição de parente, amigo, confidente, ou mesmo complicadas imbricações políticas que se esperam na devolução do trabalho do antropólogo para o grupo estudado; ou simplesmente o grupo não espera nada em troca, ou ainda isto é omitido no texto monográfico. ${ }^{27}$ Seja como for, poucos devem ser os casos em que ao objeto interessa mais conhecer o etnógrafo do que ser conhecido por ele. Este é um dos sentidos que o ex-oficial acima insistiu em apontar para a pesquisadora durante toda a sua entrevista.

De fato, nesse pequeno mas ilustrativo excerto de fala, percebi uma recorrência de fatos já vistos em trabalhos anteriores (Leirner 1997, 2006). Em primeiro lugar, a absoluta diferença no sentido das informações quando se está falando com militares da ativa ou da reserva. Durante os primeiros anos da pesquisa de campo, percebi sistematicamente que meus informantes da ativa eram muito mais marcados pelo silêncio e por omissões do que por informações que chegavam até mim. Os reformados, pelo contrário, sempre se diziam "liberados" para falar, e ocupavam caixas de fitas cassete com informações. De maneira análoga, era comum - como descrito acima que oficiais da ativa me "esquecessem", obrigando-me a voltar para a "estaca zero" da pesquisa constantemente.

Uma situação bem ilustrativa disto foi durante uma visita a uma unidade militar, em 1995, quando percebi que o oficial que havia me convidado, ao me ver chegando, saiu agachado por trás de alguns móveis até a garagem da unidade, pegou uma viatura e "saiu". Apesar do lado patético da situação, visto que ele próprio insistira no convite um dia antes, cheguei à conclusão de que a situação correspondia a uma repetição de elementos que vi uma série de vezes: convites "furados", ordens "que não chegavam" e/ou "lapsos" de informação - isto quando simplesmente se fazia o convite e, ao se chegar ao local, ouvia-se: "acho que isso não é aqui, dirija-se ao...", fato que ocorreu comigo e com outros. Um de meus orientandos notou que esse procedimento é inclusive comum no despacho de documentos: uma carta pedindo para dar acesso a uma unidade militar percorreu o trecho São Carlos-São Paulo-Brasília ida e volta duas vezes, até ter se "perdido" no meio do caminho na terceira vez. 
Tais eventos apontam para sentidos diferenciados na "troca de palavras": se os da ativa "recebem e não devolvem", os da reserva tranquilamente "dão sem pedir de volta". ${ }^{28}$ Mas evidentemente esta é só uma parte das coisas. O mais interessante é, sem dúvida, o deslocamento em relação a quem interroga e quem responde. Normalmente chamamos nossos interlocutores de "informantes"; na linguagem militar, isto significa alguém que "trabalhe" para eles, infiltrado nas linhas inimigas. Muitas vezes me senti neste papel: era comum passar pela sabatina relacionada às minhas intenções, à minha carreira, à minha instituição de pesquisa, o que achávamos (a instituição, os antropólogos) da Amazônia, dos índios, se éramos comunistas e, principalmente, qual era a visão que tínhamos do exército. Em muitas ocasiões percebi técnicas de interrogatório, com perguntas idênticas sendo repetidas algumas vezes em momentos intermitentes. O mesmo se pode dizer de cartas, projetos e intenções de pesquisa: eu e meus alunos passamos várias vezes por um processo que incluiu reescrever a mesma coisa, "especificar melhor", dar mais detalhes etc. Como dissemos acima, isto era acompanhado de tarefas e instruções. Some-se ainda o fato de que depois escrevi cartas mandando meu trabalho e tive respostas com apontamentos: "isso está errado, isso está certo" etc.

É notável que instituições militares como o exército brasileiro costumem ter controle de praticamente tudo o que se escreve ou o que se diz a respeito delas. Cada unidade militar no Brasil - e creio que isto se repete para grande parte dos exércitos (Leirner 2001) — tem uma seção específica que é responsável por coletar informações locais onde e quando aparecer o termo "exército", "militares" etc. No caso brasileiro, isto é feito pela $2^{a}$ seção das OMs (organizações militares), que fazem a coleta do material, organizam, resenham e mandam para cima na cadeia de comando. Por exemplo, é comum, como atesta C. Castro (comunicação pessoal), que militares tenham lido a resenha do livro dele, elaborada pelo comando em Brasília. O que importa, nessa situação, é que a cadeia de comando tenha capturado a informação e a tenha processado em seu interior.

No caso de minha etnografia, algum tempo e vários contatos e tentativas de contatos estabelecidos depois, me foi recomendada a tutoria por um militar (da ativa) que saberia responder àquilo de que eu necessitava. Por dois anos fui acompanhado por ele que, inclusive, estava presente em sessões de congressos como a ANPOCS junto com uma equipe de comandados, que cuidadosamente anotava tudo o que ouvia nas mesas e nas conferências. Tal sujeito, eu soube depois, ${ }^{29}$ era o que se chamava E-2, ou seja, oficial de informações de um setor do Quartel General de Brasília, destinado a detectar as representações do universo das ciências sociais sobre o exército. 
Um detalhe interessante é que ele tinha doutorado em sociologia por uma universidade importante do Brasil. A seu modo, o exército também treina seus "inventores da cultura" (Wagner 1981) para detectarem essa outra tribo, no caso, antropólogos, sociólogos.

Não deixa de ser interessante o fato de que existe um departamento específico que cuida de "relações públicas" com o "mundo de fora", as $5^{\text {as }}$ seções das OMs, que tanto filtram os sinais do exterior "para dentro", quanto mandam de volta "para fora" a relação com o universo paisano. Idealmente, os oficiais responsáveis por elas devem passar por cursos no Centro de Estudos de Pessoal do Exército (CEP), onde se estabelece todo um programa de "como se relacionar" com o mundo de fora (Albertini 2008). Na época em que estava concretamente em campo, por volta de 1995, cheguei a conhecer alguns oficiais do CEP, vários dos quais me foram apresentados por serem de uma área "próxima", a psicologia.

Na época pouco valorizei tal fato; hoje, para voltar aos militares-antropólogos como David Kilcullen, esses centros de estudo associados a uma formação em psicologia estão na crista da onda entre militares. Tratam sobretudo das chamadas "operações psicológicas" (OPsi): "táticas de contrainformação", "técnicas de interrogatório" e "propaganda". Seria o equivalente "milicológico" das nossas disciplinas de "métodos", "pesquisa de campo" etc. Creio que, em função do cenário atual (digo, dos anos 1960 para cá, com as guerras de descolonização), de predominância de guerras irregulares, movimentos insurgentes, terrorismo e aquilo que os próprios militares chamam de "choque cultural", todo esse movimento de aproximação com a antropologia tem se efetuado e sido traduzido em práticas de OPsi, como bem já previra Bateson depois da $2^{\mathrm{a}}$ Guerra.

Mesmo que consideremos este movimento como parte de uma relação maior de "administração de alteridades" (Lima 1995), e ainda que boa parte da "utilidade" dos antropólogos resida em apreender seus métodos e (duplamente) convertê-los para que trabalhem com(o) militares, é preciso lembrar que estamos diante de um campo com uma enorme quantidade de variáveis contextuais. Podemos ser "amigos" ou "inimigos" do exército em uma série de circunstâncias e sempre estar comutando essas duas posições. É verdade que muitas vezes presenciei confusões em situações como "um antropólogo deve naturalmente ser amigo de índios, então, nosso inimigo"; ou ainda "somos os verdadeiros amigos dos índios, você pode ser nosso amigo"; ou, das mais surpreendentes, "é um 'barato' ser nativo, nunca achei que fosse ser um...".

Todas estas posições são, portanto, relacionais e contextuais. Se, como me disse um coronel, "os EUA eram nossos amigos, agora não são mais", também 
podemos sê-lo, ou não. Mas, assim como nos EUA, é preciso que antropólogos da mesma forma que os demais responsáveis por um "projeto nacional", como sempre me foi colocado — sejam inseridos em uma lógica de "estreitamento de relações", do jeito que for. O cenário atual (pós-11 de setembro), aliás fundado em uma enorme dissimulação do campo da guerra, bem como uma centrifugação dificilmente previsível das forças mostram que as OPSi têm sido um dos principais recursos das várias máquinas de guerra espalhadas pelo mundo e, sem querer extrapolar demais os "efeitos colaterais" de etnografar militares, me pergunto também o quanto de "operação psicológica" é utilizado nas táticas de atração e conversão de antropólogos e seus trabalhos.

Mas sem querer entrar no mérito da questão militar propriamente dita, o que nos interessa é que de alguma maneira é possível perceber a conexão entre as OPsi e a relação com o "mundo de fora", o que eles chamam de "relações públicas", e isto está devidamente etnografado (Leirner 2001; Albertini 2008). Entre essas relações está, evidentemente, aquela com pesquisadores em geral, e etnógrafos em particular. O que quero chamar a atenção neste ponto, voltando ao que já foi colocado, é que as trocas entre etnógrafos e militares podem ser vistas como uma extensão da modalidade de guerra que imprime suas marcas no mundo militar. Enfim, não se trata de abstrair a noção da troca etnográfica a uma forma de guerra, tal como Lévi-Strauss, que apontava as guerras como "transações comerciais malsucedidas" (1976 [1943]). Trata-se aqui de pensar a etnografia, neste caso, como uma "continuação da guerra por outros meios".

Um dos estranhos resultados ou efeitos que percebi depois do término de minha primeira etnografia foi o incrível fechamento para novas pesquisas dos locais em que estive. Curiosamente, um outro pesquisador - cientista político e ao mesmo tempo ex-militar — e que pesquisou em lugares próximos aos que eu frequentava, e que terminou sua dissertação em um momento muito próximo ao que terminei a minha, notou o mesmo fechamento. Ambos achamos que a "culpa" era nossa; afinal, como entender que simplesmente de uma hora para outra uma simples biblioteca de uma escola militar tivesse a consulta restrita a militares? Quando finalmente encontrei um militar conhecido e perguntei o que havia conhecido, tive como resposta um inconclusivo "você sabe...". Obviamente não "sabia"; aliás, sabia através dos efeitos colaterais que o silêncio era a resposta para a "minha cadeia de comando" — "universidade" — que então precisaria ir para a "geladeira", de certo modo, a mesma "geladeira" que "esfria" documentos ou requisições, que induz o pesquisador a circular numa cadeia inconclusiva.

Algum tempo depois, também vivi os "efeitos cíclicos" das coisas a que estava acostumado. Numa incursão acertada pelos próprios militares 
na Amazônia, Celso Castro me convidou para enfim acompanhá-lo em uma visita aos pelotões de fronteira, percorrendo várias unidades durante alguns dias. Subitamente, no dia do embarque no avião militar, já em Manaus, nosso nome misteriosamente havia "sumido" da lista de passageiros e, naquela época do ano (dezembro), "nunca se sabe quando um avião novamente vai partir para aquelas bandas..." - disse posteriormente um oficial, tentando consertar a situação. Mas poderíamos ter um consolo: uma excelente visita ao "Centro de Instrução de Guerra na Selva", em Manaus, "onde muitos turistas vão. Tem até um zoológico com uma bela onça, que é o mascote nosso aqui..." - repetia ele.

Alguns anos se passaram. Pelo visto saímos, em alguma hora nesse período, da "geladeira" em que os pesquisadores brasileiros se encontravam há dez anos atrás. Podemos ir novamente à biblioteca militar, ou refazer todo o percurso de pesquisa. O mais incrível, nesta hora, é que meus alunos, ao indagarem de militares algo sobre mim ou sobre o passado de pesquisas na instituição, se deparam com o vazio - e no caso benéfico - do esquecimento. Hoje, "ninguém" ouviu falar daquelas etnografias feitas durante a década de 1990, relatam-me alunos que lá vão pesquisar. Às vezes, "um ou outro ouviu falar, mas não sabe bem o que é" - me contou uma orientanda. Nada pessoal, agora tenho certeza de que este é mais um dos "efeitos da cadeia de comando". Provavelmente, esse é um ciclo que se repetirá algumas vezes... provavelmente... pois, como me disseram, "a guerra é o campo da incerteza por excelência".

Recebido em 24 de junho de 2008

Aprovado em 10 de novembro de 2008

Piero Leirner é professor do Departamento de Ciências Sociais e do PPGAS da UFSCar. E-mail: < pierolei@ufscar.br> 


\section{Notas}

* Este artigo foi elaborado a partir de uma aula dada no âmbito de uma pesquisa de pós-doutorado realizada no ICS/Universidade de Lisboa. Agradeço a motivação que recebi de João de Pina Cabral, Igor Machado e Luiz Toledo, bem como as leituras de Luiz Abreu, Lauriani Albertini, Jorge Villela, Celso Castro, e dos pareceristas anônimos de Mana. Obviamente a responsabilidade por erros e omissões é inteiramente minha. Todas as traduções de trechos de citações são de minha autoria.

${ }^{1}$ Sobre o sentimento de choque cultural, Wagner diz: "Esse sentimento é conhecido como 'choque cultural' pelos antropólogos. Nele, a 'cultura' local manifesta-se primeiramente ao antropólogo através de sua própria inadequação; contra o pano de fundo de seus novos ambientes, foi ele próprio que se tornou 'visível'. Esta situação encontra alguns paralelos em nossa própria sociedade: o calouro entrando na faculdade, o novo recruta no exército e qualquer pessoa que se veja vivendo em um ambiente 'novo' ou estranho deve experimentar certa dose desse tipo de 'choque'. Tipicamente, a pessoa fica deprimida e ansiosa, podendo fechar-se em si mesma, ou aproveitar qualquer chance para se comunicar com os outros. Em um grau que raramente notamos, dependemos da participação dos outros em nossas vidas e também da nossa própria participação nas vidas dos outros. Nosso sucesso e eficácia como pessoas estão baseados nessa participação e em nossa capacidade de manter uma competência controlada ao nos comunicarmos com os outros. O choque cultural é uma perda do self em razão da perda desses suportes. Calouros e recrutas que, no fim das contas, se encontram em um outro segmento de sua própria cultura, logo estabelecem algum controle sobre a situação. Para o antropólogo em campo, contudo, o problema é ao mesmo tempo mais premente e mais contínuo" (1981:6-7).

${ }^{2}$ Cabe adiantar que não se trata aqui de retomar toda uma bibliografia da subárea chamada "antropologia da guerra", embora, como se verá, de alguma maneira este tema apareça como parte das relações entre militares e antropólogos (cf. notas 14 e 16).

${ }^{3}$ Excluo aqui estudos não-monográficos ou que só tiveram uma aproximação com a antropologia, ou seja, estou considerando apenas aqueles que primariamente se envolveram em uma situação etnográfica, compreendendo em alguma medida uma situação de distância ou de estranhamento simbólico, e resultando em um texto que se propõe a dialogar com outras monografias em antropologia. Excluo assim pesquisas encomendadas por Forças Armadas, bem como capítulos e coletâneas em que este tipo de relação não fica bem claro, como no volume Anthropology and the United States Military (Frese \& Harrel 2003).

${ }^{4}$ Como mostra Montero (2007:53), ainda que os salesianos se aproximem em um primeiro momento de um projeto estatal-militar de atração dos índios (Bororo), em um segundo se afasta das diretrizes de Rondon; de certa maneira, isto coloca para nós que embora tais agentes possam trabalhar em uma chave semântica por vezes semelhante, também podem estar em um campo concorrencial. 
${ }^{5} \mathrm{O}$ artigo que mais chama a atenção está publicado em The New Yorker: Knowing the Enemy: Can social cientists redefine the "war on Terror?", escrito por George Packer em 18 de dezembro de 2006: http://www.newyorker.com/archive/2006/12/18/ 061218fa_fact2. Ver também, por exemplo, o artigo da Newsweek intitulado "A Gun in One Hand, a Pen in the Other", http://www.newsweek.com/id/131752. Acesso em 24/04/2008.

${ }^{6}$ Para conhecer conexões entre carreiras de antropólogos e departamentos de Estado, ver Price $(2000 ; 2002)$.

${ }^{7}$ Segundo Joan Vincent (1990:310), o movimento da antropologia para estudar o imperialismo seria uma espécie de efeito crítico provocado pela guerra do Vietnã, sentido particularmente na reunião da AAA de 1968, e a partir daí em publicações como a do próprio Asad (1973).

${ }^{8}$ Assim, "Em contraste, a intervenção dos Estados Unidos na II Guerra Mundial, vista como resposta à barbárie nazista na Europa, era apoiada por unanimidade e exigiu, na opinião de muitos, um envolvimento ativo. Essa demanda foi impulsionada sobretudo por um grupo de antropólogos formados, significativamente, por vários discípulos de Boas, que ocuparam altos cargos em alguns departamentos e fundações universitárias e acadêmicas. Este grupo incluía Margaret Mead que, em 1939, junto com Gregory Bateson e Geoffrey Gorer, tomou parte na iniciativa de colocar a antropologia no esforço de guerra, instituindo o Committee for National Morale, com o objetivo de produzir um estudo da cultura nacional que levasse a recomendações para manter alto o moral americano durante o conflito. Também participaram desta iniciativa Ruth Benedict, Clyde Kluckhohn, Ralph Linton, George P. Murdock e Rhoda Métraux." (Neiburg \& Goldman 1998:57). É preciso notar que nem tudo é ou foram flores: houve uma nefasta participação de antropólogos norte-americanos na administração de campos de prisioneiros japoneses (Suzuki 1981). Finalmente, se faz necessário perceber que uma reação negativa — ou reflexiva - também foi protagonizada pela antropologia, especialmente em reação ao contexto da Guerra do Vietnam (Rapport \& Overing 2000:19).

${ }^{9}$ Como se vê na nota 11, a trajetória de Kilcullen, descrita na reportagem de Packer para o The New Yorker, menciona que sua tese foi defendida na área de "antropologia política". Há um erro nesta informação, possivelmente causado por uma leitura apressada e influenciada por fatos subsequentes à tese, quais sejam, o recrutamento de antropólogos pelo exército americano e a associação de Kilcullen com um antropólogo, Montgomery McFate, para escrever um manual de contrainsurgência, conforme se verá a seguir.

${ }^{10} \mathrm{O}$ artigo mais expressivo é "Twenty-eight articles: fundamentals of company level counterinsurgency" (Kilcullen 2006). Segundo Gonzáles (2007:15-16), embora em sua maior parte devedor de uma antropologia simplista, por vezes pautada por noções estruturais-funcionalistas, apresenta em contraste momentos de maior profundidade, bastante semelhantes aos textos de T. E. Lawrence (que escreveu "twenty-seven articles"). Simplista ou não, seus efeitos foram notados. 
${ }^{11} \mathrm{O}$ seguinte resumo da trajetória de Kilcullen está neste trecho da reportagem de G. Packer acima mencionada: "Kilcullen, filho de dois professores universitários de esquerda, tinha estudado contrainsurgência como cadete em Duntroon, o West Point australiano, e decidiu seguir um doutoramento em antropologia política na Universidade de New South Wales. Ele escolheu como tema de dissertação o conflito Darul Islã, realizando pesquisas com ex-guerrilheiros enquanto continuava a servir ao Exército australiano. O movimento rebelde, disse ele, foi maior do que a emergência da Malásia — doze anos de revolta comunista contra o mando britânico que foi finalmente ao chão em 1960, tornando-se um importante ponto de referência na doutrina militar sobre a contrainsurgência. Durante os anos em que Kilcullen trabalhou em sua dissertação, dois eventos na Indonésia afetaram profundamente seu pensamento. O primeiro foi o aumento na mesma região em que nasceu o Darul Islã e entre algumas das mesmas famílias de um dos mais extremos movimentos islâmicos, chamado Jemaah Islamiya, que se tornou uma filial da Al Qaeda no sudeste asiático. O segundo foi a bem sucedida luta do Timor Leste para a independência da Indonésia. Kilcullen testemunhou o primeiro na medida em que realizava o seu trabalho de campo; participou do segundo como comandante de uma companhia de infantaria [unidade de infantaria comandada por um capitão. N.A.] em uma força-tarefa das Nações Unidas. Suas experiências moldaram as conclusões sobre a contrainsurgência em sua dissertação - que ele terminou em 2001 - enquanto uma nova guerra estava prestes a começar" (Packer 2006). Para conhecer um interessante debate protagonizado por Kilkullen e o antropólogo R. Gonzáles, consultar Anthropology Today, v.23, n.3, junho de 2007.

${ }^{12}$ Note-se o seguinte excerto de seu artigo: "O combate à insurreição no Iraque exige conhecimento cultural e social do adversário. Mesmo assim, nenhum dos elementos do poder nacional norte-americano - diplomático, militar, de inteligência ou econômico - leva em consideração a cultura do adversário, quer seja na formação ou na execução da política. Essa falha de conhecimento cultural tem uma causa simples: a quase total ausência da antropologia dentro do estabelecimento da segurança nacional" (McFate 2005:44).

${ }^{13}$ A tese apresenta Turney-high na capa como professor de antropologia e sociologia da Universidade de Montana e primeiro-tenente do exército americano.

${ }^{14}$ Uma revisão extensa dessa literatura está no texto de Anna Simons (1999), atualizada por H. Gusterson (2007). Uma versão crítica dessa literatura foi abordada por Fausto (2001), e retomada por Leirner (2005).

${ }^{15}$ A ideia de "intelectual orgânico" é uma referência ao conceito similar criado por A. Gramsci (1991:7-23) para definir grupos com função diretiva e organizativa, sobretudo por sua capacidade educativa e formuladora, atuando em um campo da cultura. Embora socialmente condicionados, escapam a uma simples mecânica determinista, detendo certo grau de autonomia para formular seus próprios componentes "simbólicos" (entre aspas, pois ele não fala exatamente neste termo), ainda que constrangidos pelas relações que os grupos sociais têm no mundo. 
${ }^{16}$ Pois também é evidente que a "antropologia da guerra" é bem maior que os interesses norte-americanos, ou mesmo que a antropologia que trata de guerras não deva ser necessariamente tomada como "antropologia da guerra". Ainda que consideremos que haja um debate suficientemente denso para que se constitua um "campo" ou "área" de estudos, como mostra Carlos Fausto (2001), este também pode se destacar da imanência do utilitarismo. É verdade, contudo, que a distância que uma "antropologia da guerra" pôde estabelecer em relação ao Estado é diretamente proporcional à distância que seus objetos de estudo estabelecem em relação a ele (notadamente, a antropologia da guerra das "sociedades contra o Estado" poderia ser igualmente pensada como uma antropologia "contra o Estado")? Uma reflexão sobre a imanência do Estado (e da modernidade como um de seus efeitos) em categorias sociológicas sobre a guerra está em Leirner (2007). Uma outra reflexão, além dos limites deste artigo, seria necessária a respeito de etnógrafos que passaram "pelo meio da guerra" e não raro vitimaram antropólogos (veja volumes como Fieldwork under fire (Nordstrom \& Robben 1995) e outros, que aparecem em Simons (1999:85). Fica a sugestão.

${ }^{17}$ Este caso está detalhadamente descrito em Leirner (2006). Apenas para ilustrar, vale mencionar que cheguei a ver ideias de Lévi-Strauss — da clássica "Introdução à Obra de Marcel Mauss", que em um trecho coloca que "o observador é, ele mesmo, parte de sua observação" (1974:16) - que aparecerem figuradas como "coleta de informação", suponho que a respeito do "inimigo".

${ }^{18}$ Os textos tinham conteúdos diversos: de cópias de artigos de jornais sobre a Amazônia, textos sobre Clausewitz e o conceito de "centro de gravidade" em estratégia militar até uma seleção de frases e ditados que iam de Sun-Tzu e Patton a Lênin e MaoTsé-tung.

${ }^{19}$ Embora se saiba que a troca não seja em si "pacificadora", ela pode dar início a uma nova tensão, e contém um potencial agonístico, como já atestaram, entre outros, Lefort (1979) e Bourdieu (1996). Um interessante ensaio que retoma as posições de Lefort e Bourdieu, além da de Sahlins sobre o problema da política na relação de reciprocidade, está em Villela (2001:191-197).

${ }^{20}$ Foucault coloca entre suas hipóteses para pensar o poder político aquela que ele chama de "hipótese de Nietzsche": Nela, o poder político teria como função reinserir perpetuamente essa relação de força, mediante uma espécie de guerra silenciosa, e de reinseri-la nas instituições, nas desigualdades econômicas, na linguagem, até nos corpos de uns e outros. Seria, pois, o primeiro sentido a dar a esta inversão do aforismo de Clausewitz: "a política é a guerra continuada por outros meios" (M. Foucault 1999:23). Deste modo, pode se pensar a série guerra-política atuando, por exemplo, na absorção de certo vocabulário ligado a termos da guerra (tática, estratégia etc.) por instituições e práticas disciplinares.

${ }^{21}$ Note-se a noção de Dumont de "hierarquias artificiais" das cadeias de comando (1992:100), que entendo não se aplicar ao caso, como veremos a seguir. 
${ }^{22} \mathrm{O}$ que nos leva à noção do "decorar" uma ideia, transformar a memória em um fato do "coração", convertendo a palavra em ação.

${ }^{23}$ Esta parece também ser uma das características apontadas por Ben-Ari (1998) sobre as forças de defesa de Israel.

${ }^{24}$ Digamos que haja uma divergência entre dois militares. O que importa é que ela certamente terá que ser resolvida; essa situação não pode permanecer "estacionada" na cadeia de comando. Assim, se uma verdade ou teoria exterior abrir uma divergência na cadeia, é necessário que no fim das contas se opte por uma verdade singular.

${ }^{25}$ Duas máximas militares que ilustram esse "espírito": "Quando o cérebro não funciona, o braço flexiona!"; "Só o treinamento exaustivo leva à exaustão...".

${ }^{26}$ Assim se define o objetivo do "curso básico" dos cadetes (os dois primeiros anos na AMAN): "Nos $1^{\circ}$ e $2^{\circ}$ anos da Academia Militar ocorre a Formação Básica do futuro oficial. Os objetivos são ajustar a personalidade do cadete aos princípios que regem a vida militar, assegurar os conhecimentos que o habilitem ao prosseguimento de sua formação de oficial, fortalecer o caráter militar, preparar o combatente básico, obtendo reflexos na execução de técnicas e táticas individuais de combate, obter capacitação física e desenvolver habilidades técnicas" (retirado em 26/07/2006 de http://www.aman.ensino.eb.br/pvisaogeral.htm).

${ }^{27}$ Tal assunto já deu muito pano para a manga, seara complicada para os limites deste artigo; sugiro apenas notar que no caso de militares, ou pelo menos em casos próximos, são poucas as etnografias que conheço que discutem a relação com os assim chamados "poderosos". Em relação aos militares, além dos já citados C. Castro (1990) e P. Leirner (1997), ver M. Badaró (2006). Para a questão do controle sobre a etnografia por parte de elites, ver a introdução de Pina-Cabral \& Lima (2000).

${ }^{28}$ Não há como não lembrar de Clastres e seu famoso ensaio Troca e Poder: filosofia da chefia indígena (Clastres 1977). É claro que esses "lapsos temporais" na reciprocidade também podem ser pensados em conjunto: aqueles que falam "depois" da aposentadoria, me "devolvem" o que os da ativa apenas "escutam". Se quisermos ir em tal direção (em outra ocasião), é possível pensar nessa temporalidade da reciprocidade tomando a política de sua relação (cf. Bourdieu 1996). Para uma crítica ao problema de "devolução" do chefe em Clastres, ver Lanna (2005).

${ }^{29}$ Através de uma informação fornecida por um oficial reformado. 


\section{Referências bibliográficas}

ALBERTINI, Lauriani. 2008. Perspectivas militares da imprensa: relatório de pesquisa. São Paulo: Fapesp. Mimeo.

ALMEIDA, Mauro W. B. 2004. "A etnografia em tempos de guerra: contextos nacionais e temporais do objeto da antropologia". In: F. A. Peixoto, H. Pontes \& L. Schwarcz (orgs.), Antropologias, histórias, experiências. São Paulo: Humanitas. pp. 61-81.

ASAD, Talal (org.). 1973. Anthropology and the colonial encounter. Atlantic Highlands: Humanities Press.

BADARÓ, Máximo. 2006. Devenir militaire dans l'Argentine démocratique: une ethnographie de la socialisation des futurs officiers de l'armée de terre argentine au Collège Militaire de la Nation. Doctorat en anthropologie sociale et ethnologie, Paris, EHESS.

BEN-ARI, Eyal. 1998. Mastering soldiers: conflict, emotions and the enemy in an israeli military unit. Oxford: Berghahn.

BOURDIEU, Pierre. 1996. "Marginália: notas adicionais sobre o dom". Mana. Estudos de Antropologia Social, 2(2):7-20.

CASTRO, Celso. 1990. O espírito militar: um antropólogo na caserna. Rio de Janeiro: Jorge Zahar Editora.

CHAGNON, Napoleon. 1988. "Life histories, blood revenges and warfare in a tribal population". Science, 239:985-992.

CLASTRES, Pierre. 1977. A sociedade contra o Estado. São Paulo: Brasiliense. · 1980. Arqueologia da violência. São Paulo: Brasiliense.

COON, Carelton. 1947. "The utilization of social scientists in the overseas branch of the office of war informa- tion". The American Political Science Review, 61(4):649-667.

DUMONT, Louis. 1992. Homo-hierarchicus: o sistema de castas e suas implicações. São Paulo: EDUSP.

EPHRON, Dan \& SPRING, S. 2008. "A gun in one hand, a pen in the other". Newsweek. http://www. newsweek.com/id/131752. Acesso em 24/04/2008.

FAUSTO, Carlos. 2001. Inimigos fiéis: história, guerra e xamanismo na Amazônia. São Paulo: Edusp.

FAVRET-SAADA, Jeanne. 2005. "Ser afetado". Cadernos de Campo, 13:155-161.

FERGUSON, R. Brian. 1984. "Introduction: studying war". In: Warfare, culture and environment. Orlando: Academic Press. pp. 1-81.

FOUCAULT, Michel. 1999. Em defesa da sociedade. São Paulo: Martins Fontes.

FRESE, Pamela \& HARREL, M. (orgs.). 2003. Anthropology and the United States military. New York: Palgrave MacMillan.

GONZÁLES, Roberto. 2007. "Towards mercenary anthropology?". Anthropology Today, 23(3):14-19.

GRAMSCI, Antonio. 1991. Os intelectuais e a organização da cultura. 8.ed. Rio de Janeiro: Ed. Civilização Brasileira.

GUSTERSON, Hugh. 2007. "Anthropology and militarism". Annual Review of Anthropology, 36:155-175.

KILCULLEN, David. 2000. Political consequences of military operations in Indonesia 1945-2000: A fieldwork analysis of the political power-diffusion effects of guerrilla conflict'. $\mathrm{PhD}$ dissertation, School of Politics, University of New South Wales. 
. 2006. "Twenty-eight articles: fundamentals of company level counterinsurgency". Military Review, may-june:103-108.

LANNA, Marcos. 2005. "As sociedades contra o Estado existem? Reciprocidade e poder em Pierre Clastres". Mana. Estudos de Antropologia Social, 11(2):419-448.

LEFORT, Claude. 1979. As formas da história. São Paulo. Brasiliense.

LEIRNER, Piero C. 1997. Meia-volta, volver: um estudo antropológico sobre a hierarquia militar. Rio de Janeiro: FGV.

- 2001. O sistema da guerra: uma leitura antropológica dos exércitos modernos. Tese de doutorado. São Paulo, DA/USP.

· 2005. "Perspectivas antropológicas da guerra". BIB, 60:43-63.

· 2006. "Notas sobre a apropriação de uma etnografia: o caso da PM de São Paulo". Cadernos de Campo, 14/15:279-286.

. 2007. "Sobre o estado da guerra: perspectivas socioantropológicas". In: Ana Claudia Marques (org.), Conflitos, política e relações interpessoais. Fortaleza: Pontes/CNPq. pp. 57-80. . 2008. "Sobre 'nomes de guerra': classificação e terminologia militares". Etnográfica, 12(1):195-214.

LÉVI-STRAUSS, Claude. 1974 [1950]. "Introdução à obra de Marcel Mauss". In: M. Mauss, Sociologia e antropologia, 2vols. São Paulo: EPU/Edusp. pp. 1-48.

- 1976 [1942]. "Guerra e comércio entre os índios da América do Sul". In: E. Shaden, Leituras de etnologia brasileira. São Paulo: Companhia Editora Nacional. pp. 325-339.

LIMA, Antonio C. de Souza. 1995. Um grande cerco de paz: poder tutelar, indianidade e formação do Estado no Brasil. Petrópolis: Vozes.
LUTZ, Katherine. 2002. Homefront: a military city and the american 20th century. Boston: Beacon Press.

MABEE, Carleton. 1987. "Margaret Mead and behavioral scientist in World War II: problems in responsibility, truth, and effectiveness". Journal of the History of Behavioral Sciences, 23(1):3-13.

McFATE, Montgomery. 2005. "Anthropology and counterinsurgency: a strange story of their curious relationship". Military Review, marchapril:24-38.

MEAD, Margaret. 1979. "Anthropological contributions to national policies during and immediately after World War II". In: Walter Goldschmit (org.), The uses of anthropology. Washington, DC: American Anthropological Association. pp. 145-157.

MILLS, Charles W. 1981 [1956]. A elite do poder. Rio de Janeiro: Zahar.

MONTERO, Paula. 2007. "Antônio Colbacchini e a etnografia salesiana". Revista Brasileira de Ciências Sociais, 22:49-63.

NEIBURG, Federico \& GOLDMAN, Marcio. 1998. "Anthropology and politics in studies of national character". Cultural Anthropology, 13(1):56-81.

NORDSTROM, Carolyn \& ROBBEN, A. 1995. Fielwork under fire. Berkeley: University of California Press.

OTTERBEIN, Keith. 2000. "A history of research on warfare in anthropology". American Anthropologist, 101(4):794-805.

PACKER, George. 2006. "Knowing the enemy: Can social cientists redefine the 'war on Terror'"? The New Yorker. 18/12/2006. http://www.newyorker. com/archive/2006/12/18/061218fa_ fact2 Acesso em 25/04/2008.

PINA-CABRAL, João \& LIMA, M. A. P. 2000. Elites: choice. Leadership and succession. Oxford: Berg Publishers. 
PRICE, David H. 1998. "Gregory Bateson and the OSS: World War II and Bateson's assessment of applied anthropology". Human Organization, 57(4):379-384.

. 2000. "Anthropologists as spies". The Nation, 20:24-27.

- 2002. "Past wars, present dangers, future anthropologies". Anthropology Today, 18:3-5.

RAPPORT, Nigel \& OVERING, J. 2000. Social and cultural anthropology: the key concepts. London: Routledge.

RIBEIRO, Gustavo L. 2005. "Antropologias mundiais: cosmopolíticas, poder e teoria em antropologia". Série Antropologia, 379, Brasília, UnB.

SAHLINS, Marshall. 1981. Cultura e razão prática. Rio de Janeiro: Zahar. - 1990. Ilhas de história. Rio de Janeiro: Jorge Zahar Ed.

- 2007. The stranger-king; or, the elementary forms of political life. Palestra conferida na Unicamp. Mimeo.

SIMONS, Anna. 1997. The company they keep: life inside the U.S. military special forces. New York: The Free Press. . 1999. "War: back to the future". Annual Review of Anthropology, 28:73-108.

STOCKING JR., George. 1982. "Afterword: a view from the center". Ethnos, $47(1): 173-186$. - 1991. Colonial situations: essays on the contextualization of ethnographic knowledge. Madison: University of Wisconsin Press.

SUZUKI, Peter. 1981. "Anthropologists in the wartime camps for japaneseamericans: a documentary study". Dialectical Anthropology, 5(1):33-46.

TURNEY-HIGH, Harry H. 1942. The practice of primitive warfare. Missoula: Montana State University.

VINCENT, Joan. 1990. Anthropology and politics: visions, traditions and trends. Tucson: University of Arizona Press.
VILLELA, Jorge. 2001. "A dívida e a diferença. Reflexões a respeito da reciprocidade". Revista de Antropologia, 44(1):185-220.

WAGNER, Roy. 1981. The invention of the culture (revised and expanded edition). Chicago: University of Chicago. 


\section{Resumo}

Este artigo pretende abordar resultados e consequências da realização de pesquisas etnográficas com militares. Partindo de uma discussão mais ampla sobre a ideia de antropólogos trabalhando "com militares", pretendo posteriormente situar os resultados de uma etnografia realizada no Exército brasileiro, tomada a partir de sintomas e/ou efeitos colaterais ocorridos durante e depois da pesquisa de campo. Ao retomar a relação estabelecida, e também a que não foi estabelecida, foi possível constatar a centralidade dos conceitos de "amigo" e "inimigo", para definir um amplo escopo de ligações entre o universo militar e o "mundo de fora". Tais conceitos, de início tomados como relações derivadas de uma noção nativa de guerra, em certa medida projetam-se nas relações entre militares e pesquisadores, o que levou a tratar a etnografia, neste caso específico, em continuidade com uma noção antropológica (posteriormente transformada) de guerra: guerra como relação. A partir dessa premissa relacional, pretende-se pensar algumas consequências metodológicas para uma antropologia deste tipo de objeto de pesquisa.

Palavras-chave Militares, Etnografia, Inimizade, Antropologia, Guerra

\section{Abstract}

This article investigates the results and consequences of carrying out ethnographic research with the military. Beginning with a wide-ranging discussion of the idea of anthropologists working "with the military", I then seek to situate the results of an ethnography carried out with the Brazilian Army through the symptoms and/or collateral effects that were visible both during and after my research. By taking up the relationship that was established, and also that which was not, it was possible to observe the centrality of the concepts of "friend" and "enemy" in the definition of a wide range of ties between the military world and the "outside world". These concepts, which were initially understood to be relationships derived from a native notion of warfare, project themselves, to some extent, upon the relationships between military men and researchers, which, in this specific case, led me to approach ethnography in continuity with a, formerly transformed, anthropological notion of warfare: warfare as relation. From this relational premise, I will investigate certain methodological consequences of an anthropology of this sort of research object.

Key words Military, Ethnography, Enmity, Anthropology, War 